\title{
The Myth of International Delegation
}

\author{
Andrew T. Guzman $\dagger$ \\ Jennifer Landsidle $\dagger \dagger$
}

INTRODUCTION

We live in a world of sovereign states that lacks a supra-national government. One consequence of this reality is that states must find ways to manage their interactions without reliance on some higher coercive power. When considering a problem that affects two or more states, one solution is for the states to cooperate by entering into an agreement in which each party makes representations about how it will act. If successful, agreements of this sort make behavior more predictable and encourage value-increasing cooperative behavior.

Optimal solutions to some international problems, however, require more than a simple exchange of promises. Rather, they require a delegation of authority to some entity that, ideally, can make decisions that maximize the total gains to the parties to the agreement and perhaps even address distributional issues among states. A well-functioning international body could, for example, take into account the interests of all states in making a decision and select the course of action that provides the greatest overall benefit, even if some states are made worse off. In contrast, if the individual states must make a decision and if unanimity is the decision-making rule, deviations from the status quo take place only if the proposed change represents a Pareto improvement-meaning that at least one state benefits and none is made worse off. ${ }^{1}$

Copyright (C) 2008 California Law Review, Inc. California Law Review, Inc. (CLR) is a California nonprofit corporation. CLR and the authors are solely responsible for the content of their publications.

Professor of Law, University of California, Berkeley, School of Law.

it Attorney-Adviser, Office of the Legal Adviser, U.S. Department of State. The views expressed in this article are those of the authors and do not necessarily represent the views of the Department of State or the U.S. Government. We are grateful to Karen Alter, Curt Bradley, Larry Helfer, Judith Kelley, and participants at the Law and Politics of International Delegation Workshop held at Duke Law School. Ausra Pumputis provided excellent research assistance.

1. The proposed change may include some set of transfers to compensate those that would otherwise be made worse off. 
Requiring a Pareto improvement can prevent actions that yield gains greater than the associated losses. To give just one example, there are good reasons to delegate certain questions of international peace and security to a single body, as the United Nations (UN) attempts to do with the Security Council. If such a body were able to estimate the extent of a threat and determine an appropriate response, and if it were able to direct individual states to react appropriately, the ability of the international community to respond to threats would be greatly enhanced.

Without delegation to an international body, there are significant hurdles to creating a collective response to a problem that involves two or more states. Every state has an incentive to free ride on the efforts of others to provide security; or states that are critical to the effort may stand to gain very little from it themselves and so may refuse to participate. Absent some delegated authority, the international community will often be unable to respond effectively to problems.

There is, of course, another side to delegation. When power is delegated from domestic authorities to supra-national organizations, a variety of problems emerge that will, at least sometimes, make that delegation undesirable. Inevitably, movement to a higher authority takes the decision-making process farther from individual citizens, and so reduces democratic control. This is especially true of international delegations because the existing international structures lack effective democratic institutions and practices. Additionally, an international entity may have interests that diverge from those of the states that establish it, creating principal-agent problems. There are also concerns about capture of supra-national institutions by interest groups who could influence policy to serve their own narrow set of concerns. Other risks and problems could be enumerated, but the point should be clear: delegation carries costs as well as benefits. The question of whether there should be delegation to international entities can only be answered by balancing the relevant costs and benefits on a case-by-case basis.

When one turns to examine instances of international delegation, what becomes immediately apparent, at least to the authors, is how little of it there actually is. States have had no shortage of challenges and reasons to cooperate; yet, to date, they have delegated legislative or decision-making authority to supra-national entities in extraordinarily few instances. Moreover, in virtually every such instance, the delegation is narrowly cabined in terms of its scope, its importance, and its ability to influence state conduct.

The modest extent of actual delegation stands in stark contrast to the rhetoric that commentators sometimes employ when speaking about the subject. There is a growing and misinformed sense in some quarters that the United States and other countries have engaged (and continue to engage) in delegations to international institutions that pose a significant threat to domestic sovereignty. It is said that international organizations are granted rulemaking 
authority over important policy decisions, are leading to a trampling of American constitutional rights, ${ }^{2}$ are seeking to seize authority over global governance or become a form of global government, ${ }^{3}$ and are doing these things in many important areas of public policy. ${ }^{4}$

This sense that states have delegated important and impactful decisions to international institutions across a wide range of policy issues is simply false. It is a myth.

For those who argue against further international engagements or in favor of undermining existing ones, this myth is rhetorically useful and frequently employed. As such, it is important to challenge it to encourage policymakers and other observers to take a clear-eyed look at the actual state of international delegation, and to ensure that beneficial international actions are not defeated by an imagined surrender of sovereignty. ${ }^{5}$

In reality, examples of non-trivial international delegations are quite rare. Our efforts to find examples that would plausibly suggest a worrisome threat to sovereignty have yielded only a few instances of significant delegations, and each of them is best understood as addressing particularized concerns. These delegations do not, either individually or collectively, suggest a general trend toward greater international delegations of legislative or decision-making authority.

The two most conspicuous delegations are those made by the international community to the United Nations Security Council and by European states to

2. "Today, nary a thought is given when international organizations, like the U.N., attempt to enforce their myopic vision of a one-world government upon America, while trumping our Constitution in the process. Moreover, many in our own government willfully or ignorantly cede constitutionally guaranteed rights and freedoms to the international community." Rep. Bob Barr, Protecting National Sovereignty in an Era of International Meddling: An Increasingly Difficult Task, 39 HARV. J. on LeGIS. 299, 323-24 (2002).

3. "[The American people] see the U.N aspiring to establish itself as the central authority of a new international order of global laws and global government." Sen. Jesse Helms, Address Before the United Nations Security Council (Jan. 20, 2000), at http://www.jessehelmscenter.org/jessehelms/speeches.asp (last visited September 8, 2008).

4. "[F]or virtually every area of public policy, there is a Globalist proposal, consistent with the overall objective of reducing individual nation-state autonomy, particularly that of the United States." John R. Bolton, Should We Take Global Governance Seriously?, 1 CHI. J. INT'L L. 205, $220(2000)$.

5. Indeed, international engagement is often better described as increasing the ability of a state to exercise its sovereignty. See David Epstein \& Sharyn O'Halloran, Sovereignty and Delegation in International Organizations, 70 LAw \& ConTEMP. Pross. 77, 91 (2008) ("Barring coercion or extreme exit costs, though, participation in international organizations is voluntary and therefore should be seen as a natural extension of member states' rights and an exercise of their sovereignty ...."); Oona A. Hathaway, International Delegation and State Sovereignty, 70 LAw \& CONTEMP. Probs. 115, 122 (2008) ("[S]tates remain free from external control in any meaningful sense, for they are controlled by the decisions of the international body only so long as they agree to be. Once their agreement ceases, the control over them ceases as well."); Kal Raustiala, Rethinking the Sovereignty Debate in International Economic Law, 6 J. INT'L ECON. L. 841 (2003) (exploring the various theories that institutions such as the WTO strengthen rather than threaten sovereignty). 
the European Union. The European example is, without doubt, an extreme form of delegation. Indeed, there has been enough delegation to the European level that one could advance the case that Europe no longer represents a group of sovereign states but rather a confederation that itself has many characteristics of statehood. But the European example cannot plausibly evidence some general trend toward delegation. It arose from a unique set of circumstances following the Second World War and a remarkable series of events since that time. European states have not evidenced an appetite for similar delegations beyond Europe, and no other group of states has engaged in a similar sort of sovereignty-sharing.

The second important example is the UN Security Council. ${ }^{6}$ We address this example of delegation later in this Essay, but for the moment it is enough to point out that this delegation was made sixty years ago and has remained essentially unchanged since that time. It strains the imagination to think that although we have not seen a cascade of delegations in the intervening six decades, the existence of the Security Council somehow signals there will be more such delegations in the future.

Notwithstanding occasional doomsday proclamations of concerned commentators, ${ }^{7}$ international organizations are not dictating policy decisions to this or any other country. There are no international bureaucrats secreted away in Geneva or The Hague or Washington drafting regulations or policies that control the conduct of sovereign states. With very rare exceptions, what delegation exists tends to be highly constrained and/or involve highly technical matters. Like dragons, delegation can be scary. But, like dragons, international delegation is not something we need worry too much about. ${ }^{8}$

This Essay will begin by selecting a definition of the term "delegation." From there, we will examine those examples of delegations most often cited as threats to domestic sovereignty. These examples can be divided into three rough categories: delegations of treaty-amending or legislative authority; delegations of decision-making authority; and delegations of adjudicatory

6. Though even the extent of effective delegation in this case is debated. See Alexander Thompson, Screening Power: International Organizations as Informative Agents, in Delegation and AgenCy in International Organizations (Darren G. Hawkins, David A. Lake, Daniel L. Nielson \& Michael J. Tierney, eds., 2006).

7. See Jeremy Rabkin, Why Sovereignty Matters 34 (1998) ("Global governance, then, does not threaten to replace the American government, but it does threaten to distract and confuse and, ultimately, to weaken it."); Herbert W. Titus, Senior Legal Adviser, The Liberty Committee, Constitutional Analysis of H.R. 1146-The American Sovereignty Restoration Act of 2001, http://www.gunowners.org/fs0102.htm (stating that the United States should follow the advice of George Washington, "who cautioned his countrymen to 'steer clear of permanent alliances with any portion of the foreign world,' lest the nation's security and liberties be compromised by endless and overriding international commitments.").

8. One final point of clarification is appropriate. There is debate within the United States about the appropriate scope of delegation of authority among the various branches of the government. How much power should the President have, for example, to commit the state internationally? These questions, though important, are not the subject of this Essay. 
authority.

\section{DEFINING INTERNATIONAL DELEGATION}

One challenge that this essay faces is definitional. ${ }^{9}$ Clarity requires that we choose some definition of "delegation," but any definition is, of course, arbitrary. Neither we nor anyone else can claim that there is one "true" definition of delegation, and any given definition may omit some behavior that is of interest. However, definition matters because it frames any discussion about the concept of delegation. Although there is no consensus definition, commentators have proposed several definitions in the literature, and so we begin with those.

Hawkins, Lake, Nielson, and Tierney define delegation as "a conditional grant of authority from a principal to an agent that empowers the latter to act on behalf of the former." 10 The key element of this definition for our purposes is that the agent is entitled to act on behalf of the state. An alternative definition, proposed by Abbott, Keohane, Moravcsik, Slaughter, and Snidal, requires a grant of authority to implement, interpret, and apply rules. ${ }^{11} \mathrm{Ku}$ suggests a narrower definition under which a delegation takes place only if constitutionally-assigned federal powers are transferred to an international organization. ${ }^{12}$ Perhaps the definition most focused on international law is Swaine's requirement that there be a grant of authority to develop binding rules with legal effect. ${ }^{13}$

Bradley and Kelley offer the broadest definition of which we are aware. They define delegation as "a grant of authority by two or more states to an

9. Another challenge this essay faces is that it is difficult to demonstrate a negative. It is difficult to show that there is virtually no delegation of substantive legislative or decision-making authority because one can always be accused of overlooking some example. We address this problem by considering what strike us as the most important examples of delegation and by turning to the writings of those who are concerned about delegation to see what examples they have in mind.

10. Darren G. Hawkins, David A. Lake, Daniel L. Nielson \& Michael J. Tierney, Delegation Under Anarchy: States, International Organizations, and Principal-Agent Theory, in Delegation and Agency in International Organizations (Darren G. Hawkins, David A. Lake, Daniel L. Nielson \& Michael J. Tiemey eds., 2006).

11. Kenneth W. Abbot, Robert O. Keohane, Andrew Moravcsik, Anne-Marie Slaughter \& Duncan Snidal, The Concept of Legalization, 54 INT'L ORG. 401, 401 (2000) ("that third parties have been granted authority to implement, interpret, and apply the rules; to resolve disputes; and (possibly) to make further rules") (emphasis added).

12. Julian G. Ku, The Delegation of Federal Power to International Organizations: New Problems with Old Solutions, 85 MINN. L. REv. 71, 72 (2000) ("the transfer of constitutionallyassigned federal powers ... to an international organization").

13. Edward T. Swaine, The Constitutionality of International Delegations, 104 Colum. L. REv. 1492, 1494, 1494 n.3 (2004) ("vesting them with the authority to develop binding rules," and specifying that "the authority so vested must be capable of some kind of legal effects on the international or domestic plane: something more than pronouncements or hortatory acts") (emphasis added). 
international body to make decisions or take actions." ${ }^{\text {14 }}$ Given that our purpose here is to dispel the myth that international delegations are rampant and widespread, we have elected to adopt the broad Bradley and Kelley definition, though not without some qualifications. We do so not because we think it the best possible definition but rather because we want to be clear that our claim is not simply semantic. Though a narrower definition might make our statements here less controversial, we do not wish to exclude any actions that might be thought to surrender some substantial degree of state sovereignty or to be otherwise problematic.

To be sure, the Bradley and Kelley definition is not without its shortcomings. Generally, a definition is more useful if it applies to some set of actions by states that have features in common, and the Bradley and Kelley definition is difficult to apply, as virtually any action by a state that authorizes any international entity to do anything will constitute a "delegation." Thus, for example, the trade and environment committee at the World Trade Organization (WTO), a body without the ability to create binding rules, staffed by WTO Member States, and without any authority over anything that happens at the WTO, would represent a form of delegation. Indeed, much less important forms of authority would also fall within this definition's ambit. Any entity with the authority to call a meeting, for example, regardless of who the attendees would be, would represent an international delegation. ${ }^{15}$ By attending the Olympics, states could be considered to have delegated to the International Olympic Committee the ability to allocate medals. And of course, the establishment of any international body must entail a delegation because there are decisions that the body is entitled to make and funds it is entitled to spend. This definition does not consider the importance of the body, the discretion given to it, or the controls placed on it. ${ }^{16}$

To be sure, an ideal definition of delegation should distinguish the instances in which states surrender some degree of autonomy and authority from the many other instances in which they simply engage with the world. We

14. Curtis A. Bradley \& Judith G. Kelley, The Concept of International Delegation, 71 LAW \& CONTEMP. PROBS. 1 (2008).

15. Bradley and Kelley state that Group of Seven summits do not involve an international delegation under their definition because there has been no grant of authority "to the collective or any international body." Id. at 4 . But if one takes their definition seriously such a summit involves all sorts of delegations. There has been an international delegation by the participants in the summit to the host nation to plan the event and to expend funds on it. There has been a delegation by every state present to every other state present because the very existence of the event grants to each state the authority to speak at the event itself (a form of taking action). There has also been delegation to the Group of Seven as a collective by virtue of the fact that the group can decide, for example, to abandon the meeting or to declare it a failure without the consent of every state. Id. at 3.

16. Other problems with this broad definition include that the definition does not requires that a state possess the authority that it is alleged to have delegated. We find it difficult to understand the term delegation without the original source possessing the relevant authority in the first place. Id. at 12 . 
are of the view that a decision to establish an international organization capable of binding states to a course of action in areas of great concern to states (e.g., the Security Council) requires a different analysis than a decision to establish a group of international technocrats charged with making non-binding recommendations to states (e.g., the Working Group on Internet Governance). ${ }^{17}$

To accommodate that concern, we must adopt language to qualify the degree of delegation within the Bradley and Kelley definition. Clearly some forms of delegation (including those mentioned above) are inconsequential in the sense that there is no possibility of an unforeseen cost to the state. For example, the question of how to decorate the interior of the WTO building should indubitably be left in the hands of the institution without triggering delegation questions. Other delegations are, of course, highly consequential. For example, the enormous amount of delegation to the European Union made by the Member States of that organization would fit into this category.

All of that said, the breadth of the definition itself lends itself to case-bycase analysis, which best informs any discussion of delegation. The choice of such a broad category means that a relative analysis risks being misleading. The definition itself, then, implies that a relative assessment is impractical and we must instead examine a given instance of delegation individually to determine whether it has significant costs in terms of lost sovereignty or autonomy. ${ }^{18}$ Put another way, the selection of this definition implies that to the extent one is concerned with delegation's threat to sovereignty, much of what fits under the definition can be ignored-it is simply not a threat to even the most protective notions of sovereignty. The breadth of this definition requires that when we discuss delegation as a sovereignty concern, we carefully qualify the particular forms of delegation that merit concern.

The implications of empirical studies assessing the sovereignty costs of delegations can be misleading if one does not pay careful attention to the way in which "delegation" is defined. For example, Professor Koremenos has developed a detailed coding of international agreements with which she is able to identify the frequency with which states have delegated to international bodies. ${ }^{19}$ She distinguishes between an "internal delegation" (defined as "delegation to a collective formed by the members of the agreement themselves") and an "external delegation" (defined as "delegation to a third

17. See id. at 15 (referencing the establishment of the Working Group on Internet Governance (WGIG) by the UN Secretary General to "investigate and make proposals for action, as appropriate, on the governance of the Internet by 2005 ").

18. The term "sovereignty costs" is itself ambiguous, but we use it here simply to mean whatever aspects of a delegation one might be concerned with. This includes a restriction on a state's choice set, for example, or a surrender of the power to influence the interpretation of a treaty. Because these concerns may include other things we use the term "sovereignty costs."

19. Barbara Koremenos, When. What, and Why Do States Choose to Delegate? Characteristics of Delegation in a Random Sample of International Agreements, 71 LAW \& CONTEMP. Probs. 151 (2008). 
party outside of the agreement"). There is a good deal of information in her results, but because the definition of internal and external delegations is so broad, it is not possible to draw conclusions about the degree to which important authority has been surrendered to international bodies. After presenting some statistics from her data (more on this below), she states that "delegated bodies are involved in the implementation, revision, and monitoring of the agreement and often have the power to settle disputes and enforce compliance. The actions of delegated bodies in these functions will have real effects on signatory states." 20

While it is certainly true that international organizations and international agreements have real effects (to our knowledge no one in the debate on delegation disputes that claim), it is less obvious that these effects are a result of a surrender of sovereignty. Indeed, Koremenos' data set does not reveal a single instance (in nearly one hundred agreements) in which third parties are given the authority to "mak[e] rules/laws in addition to those stipulated in the agreement."21 In seven instances, the Member States are able to do so, but this may require unanimous consent. ${ }^{22}$ The tasks of implementing and monitoring the agreement can take place without any authority being granted to the institution beyond the authority to gather data and report to the membership. With respect to dispute resolution, the above quote from her paper reflects what Koremenos' data and our own analysis suggest: There is more delegation in the dispute settlement arena than in the "legislative" arena, an issue that we address more fully below. ${ }^{23}$

Thus, while Koremenos' results contain a good deal of interesting information about the functioning of international agreements, they do not tell us much about the extent to which delegation is problematic. This brings us back to the dominant approach used in this essay, which is to seek out instances of delegation and investigate the extent to which there has been an important turnover of sovereignty. If delegation truly is problematic as practiced, one would expect to find no shortage of concrete examples in which that is the case.

20. Id. at 5 .

21. Id.

22. Later in the article we discuss why even when amendment is possible without unanimous consent there may not be a significant delegation. Koremenos does find that a number of agreements create entities capable of making decisions based on a majority of votes case (her data also indicate that most, though not all such institutions have a one-country, one-vote rule). But because she has not qualified her definition of delegation, there is no way to know what decisions these bodies are permitted to take. These bodies could be entrusted, for example, with decisions over minor administrative issues such as the dates on which country reports are due or might be bodies charged with the administration of the organization. Id. at 5-6.

23. One additional weakness to Koremenos' approach is that it cannot easily identify the degree of delegation by looking at the treaty text by itself. As Helfer points out, "analyses restricted to formal treaty provisions can also fall prey to the converse error-incorrectly identifying modest delegations as consequential." Laurence R. Helfer, Monitoring Compliance with Un-ratified Treaties: The ILO Experience, 71 LAW \& CONTEMP. ProBs. 193, 212 (2008). 
When working with such a broad definition, one must also avoid confusion between constraints that are best attributed to international politics and those that result from delegation. To illustrate, states engage in various forms of debate on the floor of the United Nations General Assembly. The issues discussed are often important to states, and the behavior of other states impacts the choices available to a Member State as well as the costs and benefits of those choices. That reality is not the result of any delegation to the General Assembly (in the sense that it is given funding and is authorized to make decisions about its own operation) but rather is an unavoidable feature of international politics. That politics is in part played out in the General Assembly does not imply that it is the delegation to the General Assembly that constrains states. Those costs would exist even if there were no delegation. A state could withdraw from the United Nations altogether and still suffer criticism from the floor of the General Assembly. This point is important because under this broad definition of delegation virtually any place in which international relations take place will represent a form of delegation. It is only when the constraints on state action (whether political, legal, or otherwise) are a product of the delegation that the delegation becomes an issue. ${ }^{24}$

We now turn to consider various forms of potential delegation and argue that it is very difficult to identify examples of delegation of legislative or decision-making authority ${ }^{25}$ that raise meaningful sovereignty concerns. In addition, although delegations of adjudicatory authority are real, such delegations are carefully constrained. Our analysis attempts to address the most oft-cited examples of delegation.

\section{II}

\section{DELEGATIONS OF TREATY-AMENDING AND LEGISLATIVE AUTHORITY}

To the extent that such delegations exist, delegations of legislative authority involve the power of an international body to change the rules. Most often, the constituting agreement provides no authority for the organization to adopt new rules without unanimous consent and there is no expectation that it will engage in policymaking going forward. Sovereignty concerns might arise, however, if there is an amendment provision that could theoretically be used to give the organization or some subset of states the power to amend the agreement without the full consent of the members. ${ }^{26}$ As discussed below, such

24. It is surely the case that the distinction between politics that are the result of delegation and politics that are not will be difficult to identify in many instances. The key point, however, is not so much how one would make this distinction in close cases but rather that it must not be ignored in easy ones.

25. See Swaine, supra note 13, at 1506 (defining general categories of delegations, including delegations of treaty-amending authority and delegations of "more standard" legislative authority).

26. Id. at 1506. It is important to notice that an amendment provision is a type of delegation once-removed. Member States established the organization by agreement and consented to some 
concerns have been raised with respect to the International Labor Organization (ILO), International Monetary Fund (IMF) and the World Trade Organization (WTO). Sovereignty concerns might also arise if the constituting agreement is subject to a novel or unexpected interpretation by some entity other than the members themselves. An often-cited example is the UN Human Rights Committee's interpretation of the impact of states' reservations to the International Covenant of Civil and Political Rights.

\section{A. Concern Over Amending Agreements Without Consent}

\section{The International Labor Organization}

One potential example of the first type of legislative delegation is the Constitution of the International Labor Organization (ILO). Although its founders explicitly rejected delegating substantial legislative authority to the organization, Article 36 of the Constitution of the International Labor Organization (ILO) provides that the Constitution may be amended by a twothirds majority. ${ }^{27}$

The existing ILO rules are entirely unobjectionable from a sovereignty perspective; for the most part, the Constitution describes the organizational structure and procedures for holding meetings, voting or for adopting proposals and recommendations. While the ILO does monitor government and privatesector conduct, it cannot adopt rules that are binding on states, and it cannot order sanctions or take any action against a state that does not comply with its labor standards. The concern, then, is that the Constitution of the organization could be changed by something less than unanimous consent. If the Constitution were changed, for example, to state that the ILO had the power to bind ILO member governments as a legal matter, the non-consenting parties could become subject to rules to which they had not consented.

The ILO represents a delegation under the Bradley \& Kelley definition, but it stretches credibility to think that it represents a meaningful threat to sovereignty. To begin with, the sort of amendment described above would probably never occur. It would fly in the face of deeply engrained notions of consent in international law and would provoke cries of protest from the nonconsenting states. Indeed, we are unable to think of a single example in which an international organization has amended its constitution to grab power in such a manner.

Moreover, if a subset of members sought to make such a change, it is

set of functions and obligations, including the amendment provision itself.

27. Id. at 1504. In addition to a two-thirds majority, passage of an amendment requires the votes of five of the ten Members represented on the Governing Body as members of chief industrial importance. These members include the United States, Germany, Brazil, China, France, India, Italy, Japan, Russia, and the United Kingdom. 
certain that the dissenting members would reconsider their membership in the organization. The ability to exit gives states protection against nonconsensual changes to the structure of an organization and dramatically reduces the seriousness of the delegation. ${ }^{28}$ As has been pointed out in other contexts, there is a balance between exit and voice. ${ }^{29}$ Conventional international commitments can be changed only with unanimous consent, giving every state considerable voice. If amendments can change the underlying rules, states have the opportunity to exit. The result is that an attempt to use the amendment provisions of an organization to change fundamentally the obligations of Member States represents a re-opening of negotiations on the structure of the organization; whatever new structure emerges, no state is committed to it.

Thus, to automatically label any provision that allows an international body to change its constitution a troubling delegation seems, to us at least, a considerable exaggeration. Imagine, for example, an international commission convened to address judging scandals in Olympic figure skating. Even if its decisional processes allowed it to change its constitutive terms by vote, we are not worried that the commission will declare itself capable of issuing binding rules of international law beyond the scope of its expertise, such as rules governing the law of the sea.

Returning to the example of the ILO, the organization's Constitution is, in reality, a rather innocuous document that merely describes the organization and procedures of the institution and which allows withdrawal by its members. Substantive obligations are promulgated through subsequent conventions, which only bind those members who choose to ratify them. ${ }^{30}$ However, there is one instance in which an ILO action has arguably taken the form of committing members to a substantive rule without their consent.

The ILO Declaration on Fundamental Principles and Rights at Work provides a set of basic labor rights that seem to bind all members, whether or not they have consented to relevant ILO Conventions. Although the Fundamental Declaration was not adopted by consensus (it did, however, enjoy the support of a large majority), it purports to bind states that have not

28. Withdrawal under such conditions would be justified under international law, even if the organization did not explicitly provide for withdrawal. Article 62 of the Vienna Convention states that a state may withdraw in response to a fundamental change in circumstance if the effect of the change is "radically to transform the extent of obligations still to be performed under the treaty." Vienna Convention on the Law of Treaties art. 62, May 23, 1969, 1155 U.N.T.S. 331 [hereinafter Vienna Convention]. A change from an organization without rule-making authority to one with such authority would surely qualify.

29. Albert O. Hirschman, Exit, Voice and loyalty: Responses To Decline in Firms, Organizations, ANd States (1970); J.H.H. Weiler, The Transformation of Europe, 100 YALE L.J. 2403 (1991).

30. ILO Constitution art. 19.5(e), June 28, 1919, 49 Stat. 2712, 225 C.T.I.A. 373 [hereinafter ILO Constitution]. In the event that an ILO convention is adopted by a two-thirds majority, Article 19.5(b) requires all Members to bring the convention before the domestic authorities responsible for ratifying treaties. The obligation on Members ends there. 
consented to it, and so may represent an example of action based on delegated authority. The language of the Fundamental Declaration is as follows:

All Members, even if they have not ratified the Conventions in question, have an obligation arising from the very fact of membership in the Organization to respect, to promote and to realize, in good faith and in accordance with the Constitution, the principles concerning the fundamental rights which are the subject of those Conventions. ${ }^{31}$

The fundamental rights at issue include: freedom of association and recognition of the right to collective bargaining; elimination of all forms of forced or compulsory labor; effective abolition of child labor; and elimination of discrimination in respect of employment and occupation. ${ }^{32}$

Before this example is offered as evidence of worrisome delegated authority, however, notice how carefully it is worded, and the actual content of its legal implications. The declaration states that members have an obligation "arising from the very fact of membership" to promote these rights "in accordance with the [ILO's] Constitution." ${ }^{\text {"33 }}$ Whatever obligations apply, then, are ultimately derived from the Constitution and the fact of membership.

Accordingly, the Fundamental Declaration must be one of two things. First, if the Constitution does not provide these obligations, the declaration is meaningless and has no legal effect. Second, if the Constitution does provide for these obligations, then the declaration simply restates them. In neither case is this an exercise of delegated authority; instead, it is a claim about what the Constitution of the ILO requires. Finally, note that that there is no authority granted to the General Conference of the International Labor Organization, the body that adopted the Declaration, to engage in interpretations of the Constitution, and so there is no sense in which the declaration represents an official interpretation of the Constitution. ${ }^{34}$

None of this is to deny that this or other declarations might have political implications. ${ }^{35}$ When international organizations are established, they can alter political costs and benefits, often in ways that cannot be confidently predicted. But there is a large difference between this kind of declaration and a true,

31. ILO Declaration on Fundamental Principles and Rights at Work art. 2, adopted June 18, 1998, 37 I.L.M. 1233, available at http:/www.ilo.org/dyn/declaris/DECLARATIONWEB. static_jump?var_language $=E N \&$ var_pagename $=$ DECLARATIONTEXT .

32. Id.

33. Id.

34. The International Court of Justice is charged with interpretation of ILO issues. ILO Constitution, supra note 30, art. 37.

35. In fact, as Helfer points out, the Declaration's monitoring mechanisms-which have reinforced the finding that investment is attracted, not repelled by, adherence to core labor standards-help to convince governments that compliance with international labor rules is both individually and collectively rational. Thus, the ILO provides valuable information to states and non-state actors which enhances the benefits of compliance with international rules without incurring the higher sovereignty costs of formally binding states to unconsented to legal obligations. Helfer, supra note 23, at 24. 
meaningful surrender of autonomy to an international body.

\section{The International Monetary Fund}

Another example that is sometimes discussed as a troubling delegation because of the potential for non-unanimous amendment of the constituting agreement is the International Monetary Fund (IMF) and its Articles of Agreement. ${ }^{36}$ Upon examination, however, this example is another red herring. Article 28(a) of the Articles of Agreement permits three-fifths of the members, having eighty-five percent of the voting power, to amend the Articles. Article 28(b), however, carves out three areas where acceptance by all the Members is required: (i) the right to withdraw from the Fund; (ii) the provision that no change in a member's quota shall be made without its consent; and (iii) the provision that no change may be made in the par value of a member's currency except on the proposal of that member. ${ }^{37}$ Absent these three substantive areas, the Articles of Agreement, much like the ILO Constitution, read like the charter of a country club. Three-fifths of the members may, for example, amend the location of the offices or the number of Executive Directors on the Executive Board, but is the delegation of these administrative decisions really cause for alarm?

\section{The World Trade Organization}

The most frequently cited example of international delegation is likely the World Trade Organization (WTO). ${ }^{38}$ While this organization certainly imposes a large number of burdensome rules on states, these rules were the product of a negotiated agreement to which all Member States consented. The claim of delegation, therefore, does not speak to the rules themselves but rather to the decision-making procedures of the organization. It is certainly true that the text of the WTO Agreement provides for decision-making by majority or supramajority voting. ${ }^{39}$ However, the most central obligations taken on by states can be changed only by consensus, ${ }^{40}$ and other changes to the substantive obligations of members take effect only for members that have accepted them. ${ }^{41}$ Importantly, there has never been any attempt to use these voting

36. See, e.g., Bradley \& Kelley, supra note 14, at 12; Swaine, supra note 13, at 1507.

37. Articles of Agreement of the International Monetary Fund art. 28, Dec. 27, 1945, 60 Stat. 1401, T.I.A.S. No. 1501, 2 U.N.T.S. 39.

38. See, e.g., Neil Siegel, International Delegations and the Values of Federalism, 71 LAW \& Contemp. Probs. 93 (2008).

39. Marrakesh Agreement Establishing the World Trade Organization arts. 4, 10, reprinted in 33 I.L.M. 1144 (1994).

40. Id. art. $10(2)$.

41. Id. art. 10(3). This provision is a bit complicated in that, after a two-thirds majority approves an amendment that would affect the rights and obligations of members, the amendment takes effect for the members that have accepted it. The Ministerial Conference (a body including all WTO members) has the authority to decide, by a three-fourths majority, that any such 
procedures; no state has demonstrated an interest in demanding that voting take place. The organization operates instead by consensus. The most reasonable conclusion is that despite the formal voting rules, WTO decisions are, and will continue to be, the product of consensus, giving every state the ability to prevent a rule change.

\section{B. Concern Over Unexpected Interpretations: The UN Human Rights} Committee

Another potential source of concern regarding legislative delegation to international bodies is the risk that an agreement or set of agreements might be subject to an unexpected or novel interpretation. While this is primarily a question for the discussion of adjudicative delegation, which is developed below, to the extent the theory arises from a source other than an adjudicator it may nevertheless be a concern.

The poster child for this concern is the UN Human Rights Committee. ${ }^{42}$ In 1994, that Committee argued that it had the right to evaluate the acceptability of reservations ${ }^{43}$ and to declare a reservation not only void but also severable, binding a signatory to the International Covenant on Civil and Political Rights (ICCPR) as if it had never issued such a reservation. ${ }^{44}$ Could this represent a delegation to the Human Rights Committee? The answer is clearly "no."

The most compelling reason to conclude that the Committee's claim should be dismissed is that its assertion, contained in the now-infamous General Comment No. 24, contradicts two rules provided in the Vienna Convention on the Law of Treaties (Vienna Convention). Article 19 of the Vienna Convention provides that a state is not permitted to attach a reservation that "is incompatible with the object and purpose of the treaty." 45 Article 20 places the primary (if not exclusive) responsibility for assessing incompatibility with State parties, with no mention of a role for any international body. ${ }^{46}$

The most preposterous aspect of the interpretation is the notion of severability. Articles 20 and 21 of the Vienna Convention set forth only two

amendment is of such a nature that any member that does not accept it must withdraw from the organization. There is, therefore, a narrow instance in which the decision would be mandatory for continued membership in the organization.

42. See Swaine, supra note 13, at 1511.

43. The Vienna Convention defines a reservation as "a unilateral statement, however phrased or named ... whereby [a State] purports to exclude or to modify the legal effect of certain provisions of the treaty in their application to that State." Vienna Convention, supra note 28, at arts. $2(1)(d)$.

44. General Comment 24, U.N. GAOR Hum. Rts. Comm., 50th Sess., Supp. No. 40, P 1, U.N. Doc. A/50/40 (1996).

45. Vienna Convention, supra note 28 , art. 19. This phrase is drawn from the International Court of Justice Advisory Opinion Reservations to the Convention on the Prevention and Punishment of the Crime of Genocide, Advisory Opinion, 1951 I.C.J. 15 (May 28).

46. Frank Newman et al., International Human Rights: Law, Policy, and Process 679 (3d. ed. 2001). 
potential consequences of reservations and objections to them: (1) either the remainder of the treaty comes into force between the parties in question, or (2) the treaty does not come into force at all between those parties. ${ }^{47}$ The Legal Adviser for the U.S. State Department accurately described the legal issue as follows:

[T]he Committee appears to dispense with the established procedures for determining the permissibility of reservations and to divest State Parties of any role in determining the meaning of the Covenant ... and of the extent of their treaty obligations ... The Committee's position, while interesting, runs contrary to the Covenant scheme and international law. ${ }^{48}$

Furthermore, the Human Rights Committee is given no authority that even suggests it is charged with interpretations of this kind. The primary role of the Committee is to study the reports of parties to the ICCPR and submit reports and comments about those reports to the parties and the Economic and Social Council. ${ }^{49}$ In addition, the Committee has a limited role in dispute resolution, ${ }^{50}$ but there is no language that can be interpreted to grant it the authority to act as it did in attempting to create a new rule to govern reservations.

The only reasonable conclusion here is that the Committee's claim about its own interpretative authority is clearly false. International law simply does not support the assertion. It follows that there is no sense in which the Committee has affected the obligations of states and there has been no exercise of delegated authority.

Overall, therefore, we are not able to find real examples of legislative delegations. Even an international body such as the WTO, which possesses a hypothetical ability to change the rules by which it operates without the full consent of its members, de facto operates by consensus.

III

\section{DELEGATION OF DECISION-MAKING AUTHORITY}

We turn now to a different category of agreements and commitments: instances in which states have delegated decision-making authority to outside bodies. This is the form of delegation that springs to mind most readily when

47. Id.; Vienna Convention, supra note 28, arts. 20-21.

48. Letter from Conrad Harper to Francisco José Aguilar-Urbina, Chairman, U.N. Human Rights Committee (Mar. 28-29, 1995), available at http://www.un.org/documents/ $\mathrm{ga} / \mathrm{docs} / 50 /$ plenary/a50-40.htm.

49. International Covenant on Civil and Political Rigths and Optional Protocol art. 40(4), adopted Dec. 16, 1966, G.A. Res. 2200, U.N. GAOR, 21 st Sess. No. 16, U.N. Doc. A/6316 (1966), 999 U.N.T.S. 171 (1967) [hereinafter ICCPR].

50. Id. arts. 41-42. 
the subject of delegation arises. The specter of governments yielding control over policymaking to the UN, the WTO, or elsewhere raises concern, and for good reason. It turns out, however, that the actual instances of delegation that we have been able to identify (or that have been pointed out to us by others) are all of a highly technical and specific nature. They are severely limited in scope and present no serious threat to the interests or the sovereignty of states. It is also noteworthy that, in these examples, the gains from delegation seem large and the costs seem negligible.

It appears that arms control and environmental agreements are more prone to this sort of delegation than other types of agreements, presumably because they often involve highly technical regulations. ${ }^{51}$ Typically, a qualified majority is permitted to adopt amendments to the body of the treaty, but those amendments will only bind the parties that ratify them. ${ }^{52}$ Some agreements allow modifications to their technical annexes under a so-called "tacit acceptance procedure," which does not require ratification by a state party for the amendment to become binding. ${ }^{53}$ However, states are usually given a period within which to object, and objecting parties are not bound by the amendment. This ability to object prevents a state from being bound to rules that it disagrees with, and thus fails to constitute a delegation that should trouble us (or, under a narrower definition, fails to constitute a delegation at all).

Some small number of agreements may appear to go further by not giving individual states the ability to exempt themselves from these technical decisions. The Montreal Protocol on Substances that Deplete the Ozone Layer (Montreal Protocol) encourages consensus, but provides that, as a last resort, a two-thirds majority may vote to adjust the limits on the production and consumption of substances specified in the annexes as depleting atmospheric ozone. $^{54}$ The potential for an adjustment without consent may appear troublesome, but the simple fact is that no adjustment has been made in the history of the Montreal Protocol with anything less than consensus. ${ }^{55}$ Furthermore, this adjustment would only apply to a State Party that has already agreed to ban the chemical altogether. ${ }^{56}$ Commentators seem to fixate on the Montreal Protocol because there is a delay between the commitment to ban a substance and the decision on the rate at which to eliminate it. Although this

51. Comm. on Foreign Relations, U.S. Senate, io6th Cong., Study on Treaties and Other International Agreements 182 (Comm. Print 2001).

52. Swaine, supra note 13 , at $1512,1512 \mathrm{n} .71$ (providing a list of examples of such agreements).

53. Id.; see also Curtis A. Bradley, Unratified Treaty Amendments and Constitutional Process (Feb. 2, 2006) (unpublished workshop paper, on file with author).

54. The Montreal Protocol on Substances that Deplete the Ozone Layer art. 2.9(c), Sept. 16, 1987, S. Treaty Doc. No. 10, 100th Cong., Ist Sess., 26 I.L.M. 1541 [hereinafter Montreal Protocol].

55. Duncan B. Hollis, Why State Consent Still Matters-Non-State Actors, Treaties, and the Changing Sources of International Law, 23 BERKELEY J. INT'L L. 137, 171 (2005).

56. Controls over new chemicals apply only to parties that ratify the relevant amendment. 
delay may cause domestic political problems if, for example, the executive administration that committed to eliminate the chemical changes during the lag period, it is not entirely clear why this delay implicates greater sovereignty concerns than a one-time decision to ban a chemical completely.

Several international organizations issue non-binding standards that have gained influence under the WTO system. The Codex Alimentarius Commission is an international organization created by the Food and Agriculture Organization (FAO) and the World Health Organization (WHO) to develop non-binding food standards and codes of practice in order to protect consumers and ensure fair trade practices in food trade. ${ }^{57}$ Although these standards are not binding on their own, the Technical Barriers to Trade (TBT) and Sanitary or Phytosanitary Measures (SPS) Agreements encourage their adoption by Member States by granting presumptive validity to food safety standards set by the Commission. ${ }^{58}$ Similarly, the SPS Agreement recognizes the International Office of Epizootics as issuing acceptable international standards, guidelines and recommendations for animal health and zoonoses, ${ }^{59}$ and the Secretariat of the International Plant Protection Convention for international standards in plant health. ${ }^{60}$ Thus, this represents a real delegation, in that these international entities are able to influence indirectly the rules under the SPS and TBT Agreements. The scope of this ability to influence rules, however, is extraordinarily narrow and, in any event, the rules in question serve only as default rules that allow for deviation under appropriate circumstances.

Another example that is sometimes cited is the International Atomic Energy Agency's (IAEA) Model Additional Protocol. Article 16(b) provides that a majority of the IAEA Board of Governors may (after consultation with experts) amend the activities, equipment, and material covered by the annexes without ratification by the States Parties. ${ }^{61}$ Prior to the adoption of this Protocol, each state had a veto over such decisions. One credible view of this Protocol is that it has only a negligible impact because it does not eliminate the

57. See Codex Alimentarius, http://www.codexalimentarius.net/web/index_en.jsp (last visited Aug. 5, 2008).

58. Agreement on the Application of Sanitary or Phytosanitary Measures, Apr. 15, 1994, art. 3.2, 3.4, Annex A(3)(a) in Final Act Embodying the Results of the Uruguay Round of Multilateral Trade Negotiations, Apr. 15, 1994, 33 I.L.M. 1125, 1381, reprinted in III COMPILATION OF INTERNational Laws 273 (FDLI 1996) [hereinafter SPS Agreement]; Agreement on Technical Barriers to Trade, Apr. 15, 1994, art. 2.5, in Final Act Embodying the Results of the Uruguay Round of Multilateral Trade Negotiations, Apr. 15, 1994, 33 I.L.M. 1125, 1427, reprinted in III COMPILATION OF INTERNATIONAL LAWs 281 (FDLI 1996) [hereinafter TBT Agreement].

59. Zoonoses are diseases or infections naturally transmitted between vertebrate animals and humans. Zoonoses and Veterinary Public Health, World Health Organization, at http://www.who.int/zoonoses/en/ (last visited Sept. 29, 2008).

60. SPS Agreement, supra note 58, at Annex A(3)(b)-(c).

61. Model Protocol Additional to the Agreement(s) Between State(s) and the International Atomic Energy Agency for the Application of Safeguards art. 16(b), IAEA Doc. INFCIRC/540 (Sept. 1997) (corrected) [hereinafter Model Protocol]. 
national security exception contained in the IAEA's Safeguards Agreement. ${ }^{62}$ This exception gives states the ability to avoid legally any amendments of consequence. Furthermore, the ability to amend is limited to the activities listed in Annex I and the material specified in Annex II. Under Article II, states are required to provide the Agency with a declaration containing a description of the scale of operations for each location engaged in the activities specified in Annex I and "the identity, quantity, location of intended use in the receiving State and date or ... expected date, of export" of the specified equipment and non-nuclear material listed in Annex II. ${ }^{63}$

To be clear, if one dismisses the national security exception in contrast to the other examples discussed up to this point, we judge this example to represent a non-trivial delegation of authority. We nevertheless suggest that there is no cause for alarm. This is an instance in which some delegated rulemaking seems highly desirable in the sense that a consensus-based approach to regulating nuclear activity and preventing violations of the Non-Proliferation Treaty has obvious and severe problems. So although there is a real delegation, it is highly cabined and subject to a national security exception.

Similarly, the Organization for the Prohibition of Chemical Weapons (OPCW) is charged with the implementation of the Chemical Weapons Convention (CWC). Under the CWC, each State Party undertakes to destroy chemical weapons it owns or possesses (or any weapon located in any place under its jurisdiction or control). ${ }^{64}$ The OPCW is comprised of three organs: the Conference of States Parties, the Executive Council and the Technical Secretariat. These organs ensure compliance with the CWC by engaging in fact-finding and legal evaluations and reacting to violations. ${ }^{65}$

For our purposes, the most problematic situation is one in which a State Party is suspected of non-compliance. ${ }^{66}$ In that context States Parties are encouraged to "first make every effort to clarify and resolve" the matter "through exchange of information and consultations among themselves." However, a State Party may also request that the Technical Secretariat order an on-site challenge inspection. ${ }^{68}$ In such a case, the challenged State would be obligated to permit an inspection team to access the pertinent facilities, or

62. Id. art. 1 .

63. Id. art. 2(a)(iv), 2(a)(ix).

64. Convention on the Prohibition of the Development, Production, Stockpiling and Use of Chemical Weapons and Their Destruction art. I.2, opened for signature Jan. 13, 1993, U.N. GAOR, 47th Sess., Supp. No. 27, U.N. Doc. A/47/27, App. I (1992) [hereinafter CWC].

65. Mike Nishimura, Constraints on Sovereignty in the Chemical Weapons Convention from the Perspective of International Law, in Sovereignty AND THE Global Community 6I (Howard M. Hensel ed., 2004).

66. Although the CWC does not specify which obligations are subject to challenge inspections, non-compliance with fundamental obligations implying "a damage for object and purpose of the Convention" would probably justify the use of a challenge inspection. Id. at 61-62.

67. CWC, supra note 64, art. IX.2.

68. Id. art. IX.8. 
"requested perimeter," as soon as possible but no later than 108 hours after the team arrived at the "point of entry." Inspection teams are always guided by the principle of conducting inspections "in the least intrusive manner possible, consistent with the effective and timely accomplishment of its mission.,"70

The inspection team will render a report of its findings, and the Executive Council will determine whether the facts indicate a situation of noncompliance. In a case of non-compliance, the Council will bring the matter to the attention of the Conference of States Parties, which is ultimately responsible for deciding the measure of redress. ${ }^{71}$ The Conference may decide to restrict or suspend the offending State Party's rights and privileges under the CWC until it conforms with its obligations. ${ }^{72}$ In cases where serious damage to the object and the purpose of the CWC may result, the Conference may recommend collective measures "in conformity with international law" or, in cases of particular gravity, bring the issue to the attention of the UN General Assembly and Security Council. ${ }^{73}$

Although delegation to the $\mathrm{OPCW}$ is real, the constraints on sovereignty under the CWC regime are "not without limit and are, indeed, relative."74 First and foremost, no State Party has asked yet for an intervention of the OPCW (under Article IX, paragraphs 3-7) in obtaining a clarification from another State Party, and no State Party has requested a challenge inspection. ${ }^{75}$ Second, there are two types of authority granted. The first is a form of quasiadjudicative authority in that the Conference of the Parties ultimately can determine what to do about non-compliance. This category of delegation is addressed in the next section of this Essay. The other potential delegation is the right to carry out an inspection. That is, the parties to the Convention have delegated the decision about whether an inspection is to take place. This too is a real delegation, but it is very limited, as the only risk is that of an inspection to promote compliance with the agreed-upon rules of the convention. Finally, the CWC contains a withdrawal clause that recognizes the security interests at stake for the States Parties. If and when a State "decides that extraordinary events, related to the subject-matter of [the] Convention, have jeopardized the supreme interests of its country," it may withdraw from the regime, although it is required to provide notice including a statement of such events. ${ }^{76}$

69. Id. Verification Annex, Part X.C.38-39.

70. Id. Verification Annex, Part X.C.45.

71. Nishimura, supra note 65 , at 62.

72. CWC, supra note 64 , art. XII.3.

73. Id. art. XII.3-4.

74. Nishimura, supra note 65 , at 70 .

75. Id. (reporting as of May 2003).

76. CWC, supra note 64 , art. XVI.2. Although States Parties are required to provide some statement, "in reality, almost any statement made by the withdrawing State will be accepted as a valid notice of withdrawal, for the clause gives very little clue, if any, as to the criterion for validity of this notice." Nishimura, supra note 65, at 72 . 
Another example of true delegation of decision-making authorityperhaps the most important-is the United Nations Security Council. It is clear that the Security Council can issue decisions that are legally binding on Members of the United Nations ${ }^{77}$ and represents a delegation of consequence by all UN members other than the five veto-wielding permanent members. The veto rights of the permanent members make it difficult for the Security Council to act and, therefore, constrain the extent of the delegation, but it remains true that with the exception of the permanent members there has been a real and important delegation. As such, it represents one of the rare exceptions to our general claim that delegations are rare and narrowly cabined. This exception would trouble us more if it seemed like it might signal a widespread increase in delegation by states to international bodies. Of course, it does not. The Security Council came about under unique circumstances and the sixty years since its creation have offered no evidence that it represents the start of a trend toward greater delegation.

\section{IV}

\section{DELEGATIONS TO INTERNATIONAL COURTS AND TRIBUNALS}

The focus of this Essay has been to examine the delegation of rule-making authority to international entities. Rather than delegate explicit decision-making power to such entities, states at times delegate some form of adjudicative power to tribunals. To the extent that international tribunals generate legally binding interpretations of existing rules of international law, this represents another type of clear delegation. Within the context of a few of these tribunals, we could understand concerns about whether they entail excessive sovereignty costs. $^{78}$

Even here, however, there are considerable protections in place to limit the effective power of tribunals. A careful review of these tribunals, their case loads, and their charges reveals that delegation to quasi-judicial bodies has, in reality, been modest.

Although there has been some discussion of the "proliferation" of international courts and tribunals in recent years, ${ }^{79}$ states have placed tight

77. See U.N. Charter art. 25. To cite just one example, Security Council Resolution 1373, which compels all nations-not just Security Council members-- to take specific actions against financing terrorist activities.

78. One of us has written about precisely such sovereignty costs at the WTO, though without concluding that they exceed the associated benefits. Andrew T. Guzman, Global Governance and the WTO, 45 HARv. INT'L L.J. 303 (2004).

79. See Paul Schiff Berman, Dialectical Regulation, Territoriality, and Pluralism, 38 CONN. L. REv. 929, 950 ("The proliferation of international tribunals also, of course, creates the opportunity for plural norm creation."); Benedict Kingsbury, Foreword: Is the Proliferation of International Courts and Tribunals a Systemic Problem?, 31 N.Y.U. J. INT'L L. \& PoL. 679, 679 (1999) ("The rapid proliferation of international courts and tribunals, and the increased activity of many of them, pose numerous practical problems ..."); Cesare P.R. Romano, The Proliferation of International Judicial Bodies: The Pieces of the Puzzle, 31 N.Y.U. J. INT'L L. \& Pol. 709, 709 
constraints on the authority of these institutions through a combination of limited jurisdiction, cabined discretion, and disciplinary actions such as noncompliance and withdrawal. The typical charge to international tribunals, in the few areas in which they exist, is simply to resolve disputes between states. This mandate discourages ambitious rulings, rule setting, and policy-making from the bench. Moreover, tribunals do not issue rules that generate formal legal precedent; instead, the tribunal's decision is limited to the parties in the particular case.$^{80}$ Perhaps most importantly, existing tribunals are consistently restrained and cautious. They are well aware that "judicial activism" is likely to lead to non-compliance, withdrawal, or both. Professor Alter, for example, has commented that "most of the[] rulings are exactly what states hoped for when they delegated authority to ICs." $" 81$

In addition, of course, such delegation-when it occurs-is not done without reason. Even the most skeptical commentators on international tribunals recognize that important gains can be achieved by states as a result. ${ }^{82}$ For states involved in treaty disputes, tribunals can help to resolve conflicts by discovering or revealing information about the meaning of the agreement and the nature of the allegedly infringing action. ${ }^{83}$ For states in other sorts of disputes, tribunals can discover facts, develop new rules, or apply existing rules to new unanticipated circumstances. ${ }^{84}$ At the absolute minimum, credible tribunals allow states to enter into agreements more readily and, therefore, to resolve cooperative problems more effectively. Just as private parties gain from the existence of a court system ready to enforce their contracts, states benefit from the existence of competent tribunals. The real mystery is not why we observe delegation by states to these tribunals, but rather why it is done so rarely and so cautiously.

The important constraints placed on international tribunals are best illustrated by examining some of the most often-cited examples of delegations of adjudicatory authority.

(1999) (stating that one of the most important developments in international law in the post-Cold War age has been "the enormous expansion and transformation of the international judiciary"). But see Jose E. Alvarez, The New Dispute Settlers: (Half) Truths and Consequences, 38 TEX. INT'L L.J. 405, 411 (2003) (describing the claim that "[ $t$ ] he recent proliferation of international tribunals constitutes the 'judicialization' of international law" as a "half truth" and possibly closer to myth).

80. In public international law, past decisions may be persuasive, but not binding. See IaN Brownlie, Principles of Public International LaW 1-29 (6th ed. 2003).

81. Karen J. Alter, Delegating to International Courts: Self-Binding Vs. Other-Binding Delegation, 70 Law \& CONTEMP. ProBs. (forthcoming Jan. 2008) (manuscript at 36, available at http://ssm.com/abstract=1001949).

82. Eric A. Posner \& John C. Yoo, Judicial Independence in International Tribunals, 93 Calif. L. Rev. 1, 14 (2005).

83. Id.

84. Id. 


\section{A. The International Court of Justice}

As "the principal judicial organ of the United Nations,", Court of Justice (ICJ) has a dual role "to settle, in accordance with international law, legal disputes submitted to it by States and to give advisory opinions on legal questions referred to it by authorized United Nation organs and specialized agencies." 86 Only the former is relevant to a discussion of international delegations.

An examination of the Statute of the Court demonstrates that the jurisdiction of the Court and its decision-making process are constrained in a number of significant ways. Most importantly, the Court is only competent to entertain disputes between States that have accepted its jurisdiction. A State may accept jurisdiction in one of three ways. First, after a dispute arises, the disputing States may make a special agreement between them to submit the dispute to the Court. ${ }^{87}$ However, as discussed above, dispute resolution agreements made after a dispute arises do not implicate the sorts of delegation concerns at issue here. As Eric Posner points out, the ICJ in such special agreement cases is "just a glorified arbitration panel." 88

Second, States may include a jurisdictional clause in a treaty referring a dispute over its interpretation or application to the Court. ${ }^{89}$ Although the inclusion of such a provision would constitute an international delegation, the use of such provisions is in serious decline. ${ }^{90}$ Strikingly, the United States has not used this type of clause since the early $1970 \mathrm{~s} .{ }^{91}$ Moreover, as discussed at greater length below, when faced with an adverse judgment or the threat of one, states may withdraw from the jurisdictional clause, just as the United States withdrew from the Optional Protocol to the Vienna Convention on Consular Relations (VCCR) after an unfavorable ruling in Avena and Other Mexican Nationals (Avena) ${ }^{92}$

Third, a State may make a declaration accepting the compulsory jurisdiction of the Court over certain legal disputes with other States that have made similar declarations. ${ }^{93}$ The covered legal disputes may include: the interpretation of a treaty; any question of international law; "the existence of any fact which, if established, would constitute a breach of an international

85. International Court of Justice, http://www.icj-cij.org/court (last visited Aug. 5, 2008).

86. Id.

87. Statute of the International Court of Justice art. 36(1), June 26, 1945, 59 Stat. 1055, 33 U.N.T.S. 993 [hereinafter ICJ Statute].

88. Eric A. Posner, The Decline of the International Court of Justice 9 (John M. Olin Law \& Econ. Working Paper No. 233 (2d Series), 2004), available at http://www.law.uchicago.edu/ Lawecon/index.html, at 9.

89. ICJ Statute, supra note 87, art. 36(1).

90. Posner, supra note 88 , at 9.

91. Id.

92. Avena and Other Mexican Nationals (Mex. v. U.S.), 2004 I.C.J. 12 (Mar. 31 ).

93. ICJ Statute, supra note 87, art. 36(2). 
obligation;" or the nature of extent of the reparation to be made for the breach of an international obligation. ${ }^{94}$

Of the three types of ICJ jurisdiction, compulsory jurisdiction would seem the most alarming from a delegation standpoint. At first glance, filing a declaration of compulsory jurisdiction would seem to grant the ICJ general jurisdiction over a wide variety of possible inter-state disputes. However, such fears are clearly overblown. First of all, out of 192 current UN members, ${ }^{95}$ only 65 states, or approximately one third, presently have declarations in force. ${ }^{96}$ This percentage appears to be in continuous decline; in 1950, 60 percent of UN members were subject to compulsory jurisdiction. ${ }^{97}$ Today, no permanent member of the Security Council remains subject to compulsory jurisdiction except the United Kingdom. ${ }^{98}$

Second, the number of states subject to compulsory jurisdiction belies the number of cases successfully filed under the optional protocol. From 1961 to 1987, the Court only relied on the optional protocol twice as the basis for its jurisdiction, in the Nuclear Tests Case ${ }^{99}$ and Military and Paramilitary Activities in and against Nicaragua. ${ }^{100}$ In both of these cases, the respondents, France and the United States respectively, refused to participate in the proceedings. In the Nuclear Tests Case, France refused to participate from the start; the United States withdrew after participating in the initial stages of the case with Nicaragua. ${ }^{101}$

The negligible usage of the optional protocol as a basis for ICJ jurisdiction may be due, at least in part, to states' use of reservations to severely limit the scope of their consent to compulsory jurisdiction. ${ }^{102}$ States may restrict the scope of compulsory jurisdiction by imposing conditions of reciprocity on declarations, excluding certain categories of dispute, or limiting the declaration for a certain time. ${ }^{103}$ For example, Honduras' reservation precludes compulsory jurisdiction over disputes relating to armed conflicts, territorial questions, and airspace, ${ }^{104}$ three of the primary types of cases historically adjudicated by the

94. Id.

95. See United Nations Member States, http://www.un.org/Overview/growth.htm (last visited Aug. 5, 2008).

96. See Declarations Recognizing the Jurisdiction of the Court as Compulsory, at http://www.icj-cij.org/jurisdiction/index.php?pl =5\&p2=1\&p3=3\&PHPSESSID =9d07068116022 $7 \mathrm{f} 37 \mathrm{c} 427 \mathrm{c} 2068 \mathrm{ebfled}$ (last visited September 8, 2008).

97. Posner, supra note 88 , at 8.

98. Id. at 3.

99. Nuclear Tests (Austl. v. Fr.) 1974 I.C.J. 253 (Order of Dec. 20); Nuclear Tests (N.Z. v. Fr.) 1974 I.C.J. 457 (Judgment of Dec. 20).

100. Military and Paramilitary Activities in and Against Nicaragua (Nicar. v. U.S.), Jurisdiction and Admissibility, 1984 I.C.J. 392 (Judgment of Nov. 26).

101. Gary L. Scott \& Craig L. Carr, The ICJ and Compulsory Jurisdiction: The Case for Closing the Clause, 81 AMER. J. INT'L L. 57, 65 n.49 (1987).

102. Id.

103. ICJ Statute, supra note 87 , art. 36(3).

104. Declarations Recognizing the Jurisdiction of the Court as Compulsory, Honduras, at 
ICJ. $^{105}$

Finally, especially in recent years, states have disciplined the jurisdictional arm of the World Court through non-compliance and/or outright withdrawal. Although he admits that compliance is difficult to quantify, according to Posner's calculations, the compliance rate was much higher in the ICJ's first twenty years than it has been in its last twenty years. ${ }^{106}$ Certainly, the Nicaragua case, the Iran Hostages case, and the VCCR cases stand out as highprofile examples of non-compliance. In addition, when faced with an adverse decision by the ICJ or the threat of some future adverse decision, some states have elected to simply withdraw from its jurisdiction. Since its founding, thirteen states have withdrawn their submission of jurisdiction to the ICJ or allowed their declarations to expire. ${ }^{107}$ The United States has withdrawn from ICJ jurisdiction twice: it withdrew consent for compulsory jurisdiction during the Nicaragua case discussed above and, a year after the ICJ found against the United States in the Avena case, the United States announced its withdrawal from the Optional Protocol to the VCCR. Similarly, in March 2002, Australia withdrew its consent to ICJ jurisdiction over maritime disputes in anticipation of East Timor gaining statehood and bringing a boundary claim against Australia in the World Court. ${ }^{108}$

Thus for all the fanfare surrounding the ICJ, in its sixty-plus years of operation, the Court has only delivered 104 judgments in contentious cases. ${ }^{109}$ Of these judgments, only a handful have been issued in compulsory jurisdiction cases and even fewer have been met with compliance. In light of this record, the notion that the ICJ enjoys an effective grant of general authority seems farfetched.

\section{B. The International Tribunal for the Law of the Sea}

The International Tribunal for the Law of the Sea (ITLOS) is the judicial body established by the United Nations Convention on the Law of the Sea (UNCLOS). ${ }^{110}$ Under Part XI of the UNCLOS, States are obligated to settle

http://www.icj-cij.org/jurisdiction/index.php?pl $=5 \& \mathrm{p} 2=1 \& \mathrm{p} 3=3 \&$ code $=\mathrm{HN} \quad$ (last

visited September 8, 2008).

105. Posner, supra note 88 , at 3 . As of 2004 , the most common types of case adjudicated were border disputes ( 33 times); use of force ( 22 times); aerial incident (14 times); and property (14 times).

106. Id. at 11 .

107. The following states allowed their declarations to expire or were withdrawn or terminated: Bolivia, Brazil, China, Colombia, El Salvador, France, Guatemala, Iran, Israel, South Africa, Thailand, Turkey, and the United States. INTERnational Court of Justice, I.C.J. YEARBOOK 2002-2003 No. 57127 n.1 (2003).

108. At the same time, Australia withdrew consent to ITLOS jurisdiction.

109. International Court of Justice, Cases, at http://www.icj-cij.org/docket/index.php?pl=3 (last visited September 8,2008 ). Of the 140 cases taken by the Court to date, 24 have been advisory proceedings and 12 are still pending.

110. General Information-Overview, International Tribunal on the Law of the Sea, at 
disputes concerning the interpretation or application of the Convention by peaceful means, ${ }^{111}$ and are free to choose any peaceful means. ${ }^{112}$ If the parties to the dispute have agreed to submit such disputes to a regional body for resolution, that choice will take precedence unless the parties otherwise agree. ${ }^{113}$ The dispute resolution mechanisms envisioned under the UNCLOS become relevant only if and when the parties fail to reach a settlement by other means. At that point, the parties may select one of three possible mechanisms: ITLOS, the ICJ, or an ad-hoc arbitral tribunal. Under Article 287, State Parties may choose a preferred mechanism in advance. If no such declaration is made or if the two parties to the dispute have not elected the same mechanism, the ad-hoc arbitral tribunal is the default unless the parties otherwise agree. ${ }^{114}$

As of April 2008, there were 150 States Parties to the UNCLOS but only 45 states had chosen a dispute resolution mechanism under Article 287. ${ }^{115}$ Of these 45 states, only 10 had elected the ITLOS as their first choice dispute resolution mechanism; an additional 13 had chosen ITLOS as a tie for their first choices. ${ }^{116}$ Nevertheless, that means that only 23 out of 150 State Parties or fifteen percent had elected to use the ITLOS. ${ }^{117}$

Moreover, in the decade since the UNCLOS entered into force, the Tribunal has heard only fifteen claims. ${ }^{118}$ Of these, only two were brought on the merits and the Tribunal issued a judgment in only one: M/V Saiga (No. 2). ${ }^{119}$ To date, the jurisdiction of ITLOS has been almost exclusively limited to "incidental proceedings," including claims for provisional measures and for the prompt release of arrested vessels. ${ }^{120}$ All of the above has led some to question whether the cost of maintaining the Tribunal is justified. ${ }^{121}$ Meanwhile,

http://www.itlos.org/start2_en.html.

111. United Nations Convention on the Law of the Sea art. 279, opened for signature Dec. 10, 1982, U.N. Doc A/CONF.62/122 (1982), 21 I.L.M. 1261 (1982) [hereinafter UNCLOS].

112. Id. art. 280.

113. Id. art. 282.

114. Id. art. 287(3), (5). Arbitrations are conducted in accordance with Annex VII.

115. Settlement of disputes mechanism under the Convention: Choice of procedure under article 287 and optional exceptions to applicability of Part XV, Section 2, of the Convention under article 298 of the Convention, at http://www.un.org/Depts/los/ settlement_of_disputes/choice_procedure.htm (last visited September 8, 2008).

116. Id.

117. These countries include: Argentina, Australia, Austria, Belgium, Canada, Cape Verde, Chile, Croatia, Estonia, Finland, Germany, Greece, Hungary, Italy, Latvia, Lithuania, Mexico, Oman, Portugal, Spain, Tunisia, Tanzania, and Uruguay. See id.

118. Proceedings and Judgments-List of Cases, at http://www.itlos.org/start2_en.html.

119. M/V "Saiga" (No. 2) (St. Vincent v. Guinea), 120 I.L.R. 143 (Int'l Trib.L. of the Sea 1999); Jillaine Seymour, The International Tribunal for the Law of the Sea: A Great Mistake? 13 IND. J. Global Legal STUd. 1, 2 (2006).

120. Seymour, supra note 119 , at 2.

121. See, e.g., Seymour, supra note 119; R. Churchill and V. Lowe, The LAW of THE SEA 453-459 (2d ed., 1999); A. Odede, The Basic Structure of the Dispute Settlement Part of the Law of the Sea Convention, 11 OCEAN Dev. ANd INT'L LAw 125 (1982); M. Gaertner, The Dispute Settlement Provisions of the Convention on the Law of the Sea: Critiques and Alternatives 
Tribunal presidents and the U.N General Assembly seem slightly desperate as they try to encourage more states to use Article $287 .^{122}$

In only one category of disputes must all States Parties use the same dispute settlement mechanism. All States Parties are obligated to use the Seabed Disputes Chamber of the ITLOS to resolve disputes related to activities in the International Seabed Area. However, the Seabed Disputes Chamber's jurisdiction is explicitly limited by Article 189 of the UNCLOS. Under that provision, the Seabed Disputes Chamber has no jurisdiction with regard to the exercise by the International Seabed Authority ("the Authority") of its discretionary powers. ${ }^{123}$ It may not speak to the question of whether any rule, regulations and procedures of the Authority are in conformity with the UNCLOS, nor declare invalid any such rules, regulations or procedures. ${ }^{124}$ Its jurisdiction is "confined to deciding claims that the application of any rules, regulations and procedures of the Authority in individual cases would be in conflict with the contractual obligations of the parties to the dispute or their obligations under this Convention, claims concerning excess of jurisdiction or misuse of power, and to claims for damages to be paid or other remedy to be given to the party concerned for the failure of the other party to comply with its contractual obligations or its obligations under this Convention.," ${ }^{25}$ In this manner, the Seabed Disputes Chamber is explicitly limited from making policy; its one and only function is to resolve isolated disputes.

Ultimately, therefore, although States Parties to the UNCLOS are obligated to resolve their disputes under the UNCLOS by some peaceful means, that delegation is tempered by the freedom of choice that States have to elect a dispute resolution mechanism. As non-permanent bodies, ad-hoc arbitral tribunals pose little danger to state sovereignty, and very few states have elected to delegate authority to the ITLOS, which has only issued nine judgments in twelve years ${ }^{126}$ and may be on its way into oblivion.

\section{The WTO Appellate Body}

In 1995, the World Trade Organization (WTO) Appellate Body (AB) was established under Article 17 of the Understanding on Rules and Procedures

to the International Tribunal for the Law of the Sea, 19 SAN Diego L. Rev. 577 (1982); J. W. Kindt, Dispute Settlement in International Environmental Issues: The Model Provided by the 1982 Convention on the Law of the Sea, VAND. J. OF TRANSNat'L L. 1097 (1989); J. K. Gamble, The 1982 UN Convention on the Law of the Sea: Binding Dispute Settlement?, 9 B.U. INT'L L.J. 39 (1991); T. Treves, Dispute Settlement Clauses in the Law of the Sea. Convention and their Impact on the Protection of the Marine Environment: Some Observations, 8 RECIEL 6 (1999).

122. Seymour, supra note 119 , at 12 .

123. UNCLOS, supra note 111 , art. 189.

124. Id.

125. Id.

126. Intemational Tribunal for the Law of the Sea, Proceedings and Judgments-List of Cases, at http://www.itlos.org/start2_en.html (last visited Sept. 29, 2008). 
Governing the Settlement of Disputes (DSU). The AB is a permanent body whose seven members serve four-year terms. ${ }^{127}$ Its mandate is to hear appeals from panel cases. ${ }^{128} \mathrm{AB}$ decisions are, in practical terms, binding. Technically, the Dispute Settlement Body (DSB) must adopt an $\mathrm{AB}$ report in order for it to become binding on the parties. However, $\mathrm{AB}$ reports will be adopted unless there is consensus to block its adoption. ${ }^{129}$ Consensus is unlikely, and has never happened, because the prevailing party can always be counted on to vote in favor of adopting the report. ${ }^{130}$

The practical inability of Member States to block the adoption of an $A B$ decision was an important constitutional shift from the General Agreement on Tariffs and Trade (GATT) system. GATT panels were ad-hoc, and decisions were only adopted if there was consensus for adoption. The shift to a permanent judicial body whose decisions become binding automatically unless all Members agree to the contrary has fed the growing unease over the $\mathrm{AB}$ 's potential power to engage in activist, judicial lawmaking. ${ }^{131}$

When compared to the international tribunals discussed so far, the $A B$ is quite influential. In contrast to the modest number of judgments produced by the ICJ and ITLOS, the $\mathrm{AB}$ has issued 87 reports in its thirteen-year history. ${ }^{132}$ Arguably, its constitutional space is also less restrained than that of the ICJ and ITLOS. Under DSU Article 3.2, the AB is charged with clarifying the existing provisions of the covered WTO agreements "in accordance with customary rules of interpretation of public international law." ${ }^{33}$ The DSU goes on to caution that the $\mathrm{AB}$ "cannot add to or diminish the rights and obligations provided in covered agreements." ${ }^{\text {"134 }}$ In other words, the $\mathrm{AB}$ cannot engage in

127. WTO Dispute Settlement Appellate Body, http://www.wto.org/english/tratop_e/ dispu_e/appellate_body_e.htm\#members (last visited Aug. 5, 2008).

128. Understanding on Rules and Procedures Governing the Settlement of Disputes art. 17.1, Dec. 15, 1993, Marrakesh Agreement Establishing the World Trade organization, Annex 2, Legal Instruments-Results of the Uruguay Round, 33 I.L.M. 1125 (1994) [hereinafter DSU].

129. Id. art. 17.14.

130. Richard H. Steinberg, Judicial Lawmaking at the WTO: Discursive, Constitutional, and Political Constraints, 98 AM. J. INT'L LAW 247, 263 (2004).

131. See, e.g., Claude E. Barfield, Free Trade, Sovereignty, Democracy: The Future of The World Trade Organization (2001); John Ragosta, Navin Joneja, \& Mikhail Zeldovich, WTO Dispute Settlement: The System Is Flawed and Must Be Fixed, 37 INT'L LAW 697, 748-50 (2003); Kal Raustiala, Sovereignty and Multilateralism, I CHI. J. INT'L L. 401 (2000) (expressing concern that the WTO dispute settlement system is simultaneously generative and insular); Daniel K. Tarullo, The Hidden Costs of International Dispute Settlement: WTO Review of Domestic AntiDumping Decisions, 34 LAW \& PoL'Y INT'L Bus. 109 (2002). Senator Max Baucus stated that WTO panels are "making up rules that the US never negotiated, that Congress never approved, and I suspect, that Congress would never approve." US DSU Proposal Receives Mixed Reactions, BRIDGes WKLY. TRADE News DiG., Dec. 20, 2002, at <http://www.ictsd.org/weekly/02-1220/wtoinbrief.htm> [hereinafter Baucus Statement].

132. Appellate Body Reports, at http://www.wto.org/english/tratop_e/dispu_e/ ab_reports_e.htm (last visited September 8, 2008).

133. DSU, supra note 128 , art. 3.2.

134. Id. 
rulemaking. And while there is a spectrum of public international law doctrines regarding the interpretation of rules, ranging from restrained to highly deferential, the $\mathrm{AB}$ has not shown itself to be an especially activist body. ${ }^{135}$

It is also worth noting that despite the formal power of the $A B$, it operates within a political context. Its discretion is cabined by a variety of mechanisms, including the selection of $\mathrm{AB}$ members; the threat to rewrite the DSU; criticism of decisions by Member States; defiance and non-compliance; and unilateral exit. ${ }^{136}$ Thus even though the $\mathrm{AB}$ has been granted significant authority and discretion, the political realities at the WTO have kept it in check and prevented the WTO from fundamentally altering the rights and obligations of its members. ${ }^{137}$

Overall then, although the $\mathrm{AB}$ has been given authority to interpret the WTO Agreements- a non-trivial amount of discretion and influence-we also observe several aspects of this delegation that reduce the extent to which states have surrendered authority. First, the $A B$ is limited in its jurisdiction to the WTO Agreements. Second, the AB is politically constrained; it has repeatedly demonstrated its reluctance to engage in creative interpretations, preferring to remain close to the text of the agreements. This mode of interpretation is encouraged by the rules governing disputes. ${ }^{138}$ Finally, the $A B$ is limited in its ability to generate compliance with its rulings. It can authorize the imposition of trade sanctions, but only by the complaining state, and only up to an amount equal to the harm caused by the legal violation. Member States, then, have the option to ignore such rulings when they are too burdensome.

\section{Inter-American Court of Human Rights}

The Inter-American Court of Human Rights (IACHR) was created under the American Convention on Human Rights, which was adopted in 1969 but was not ratified by the requisite number of members of the Organization of American States (OAS) for over ten years, and so did not come into force until 1978. The IACHR has issued 155 "decisions and judgments," but this count includes multiple decisions in each case (often a decision regarding preliminary objections, sometimes another on compensatory damages). ${ }^{139}$

135. Indeed, the $\mathrm{AB}$ has, on several occasions, embraced the doctrine of judicial economy, thereby limiting the scope of judicial lawmaking. Steinberg, supra note 130, at 26.

136. Steinberg, supra note 130 , at 260.

137. Id. at 275 (stating that the political constraint on the $\mathrm{AB}$ "should dampen concerns that judicial lawmaking at the WTO has become so expansive as to undermine the sovereignty of powerful states, create a serious democratic deficit for their citizens, or catalyze catastrophic withdrawal of their political support for the WTO.").

138. "Recommendations and rulings of the DSB cannot add to or diminish the rights and obligations provided in the covered agreements." WTO Dispute Settlement Understanding, art. 3.2 .

139. Corte Interamericana de Derechos Humanos, http://www.corteidh.or.cr/casos.cfm (last visited Aug. 5, 2008). 
Unlike the European Court of Human Rights (ECHR) discussed below, OAS Members do not implicitly consent to the jurisdiction of the Court by ratifying the American Convention. Instead, each nation must make a separate declaration to the Secretary General of the OAS giving unconditional consent to jurisdiction, or consent on condition of reciprocity, for a specific period or specific cases. ${ }^{140}$ To date, 24 countries have submitted to the contentious jurisdiction of the Court. ${ }^{141}$ The United States, Canada, and most Englishspeaking Caribbean states have elected not to join either the Convention or the Court.

Those states that have submitted to the Court's jurisdiction have made a delegation: decisions by the Court are binding. This delegation is tempered, however, by the lack of direct individual access to the Court; individuals must first file complaints with the Inter-American Commission on Human Rights, which may decide, in turn, to submit the case to the Court on their behalf. ${ }^{142}$ Such indirect access slows the process considerably, undoubtedly increasing the cost to applicants.

The IACHR is also severely underfunded and understaffed. The Court's 2006 budget was a paltry $\$ 1,656,300 .{ }^{143}$ Only seven judges work for the Court, and these judges only sit part-time. ${ }^{144}$

Finally, the IACHR has had trouble securing compliance with its decisions. ${ }^{145}$ As Posner and Yoo observe, the IACHR often orders two types of remedies in a case: (1) the trial and punishment of offenders along with changes in domestic law; and (2) monetary compensation for the victim(s). ${ }^{146}$ According to their analysis, "it appears that while states routinely ignore the requirement that they punish offenders or change their laws, they have often

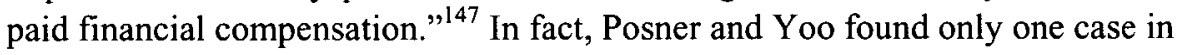
the history of the Court in which a nation has fully complied with an IACHR decision. ${ }^{148}$

140. Inter-American Court of Human Rights, at http:/www.pict-pcti.org/ courts/lACHR.html (last visited Sept. 8, 2008).

141. These countries are: Argentina, Barbados, Bolivia, Brazil, Chile, Colombia, Costa Rica, Dominica, Dominican Republic, Ecuador, El Salvador, Grenada, Guatemala, Haiti, Honduras, Jamaica, Mexico, Nicaragua, Panama, Paraguay, Peru, Suriname, Uruguay, and Venezuela. Protecting Human Rights, http://www.oas.org/key_issues/eng/Keylssue_ Detail.asp?kis_sec=2 (last visited Aug. 5, 2008).

142. Project on International Courts and Tribunals, http://www.pict-pcti.org/ courts/IACHR.html (last visited on Aug. 5, 2008).

143. 2006 Annual Report, http://www.corteidh.or.cr/informes.cfm.

144. Project on International Courts and Tribunals, http://www.pict-pcti.org/courts/ IACHR.html (last visited on Aug. 5, 2008).

145. Posner \& Yoo, supra note 82, at 42-43.

146. Id. at 43 .

147. Id.

148. Id. at 43. Posner and Yoo note that even in this case, the Honduran Disappeared Persons case, Honduras did not pay the award until eight years after the Court rendered its judgment. 


\section{E. European Court of Human Rights}

Perhaps the most effective way to demonstrate the modest nature of the delegations states make to other international courts and tribunals is to look at an example of what states do when they truly want to delegate authority to a supranational judicial body.

The European Court of Human Rights (ECHR) adjudicates cases brought by Contracting States or individuals alleging a violation of the 1950 Convention for the Protection of Human Rights and Fundamental Freedoms, more commonly known as the European Convention on Human Rights. ${ }^{149}$ Pursuant to Article 46 of the Convention, Contracting States "undertake to abide by the final judgment of the Court in any case to which they are parties." $" 150$

In contrast to the IACHR, the number of judges on the ECHR increases equal to the number of Member States to the Convention, currently fortyfive. ${ }^{151}$ The job is full-time. ${ }^{152}$ The current annual budget of the ECHR is 53.46 million euros, ${ }^{153}$ or $\$ 88,669,985.19 .{ }^{154}$

Probably the most important difference between the ECHR and other regional human rights tribunals is the fact that, after domestic remedies have been exhausted, any state party, individual, group, or NGO may bring a suit alleging a human rights violation against one of the Member States. ${ }^{155}$ Originally, a Member State could elect not to submit to ECHR jurisdiction in cases brought by non-states, but, in 1998 , jurisdiction was made compulsory for all complaints. ${ }^{156}$

The number of applications filed with the ECHR annually is entirely unmatched. In 2005 , a staggering 45,500 applications were filed. ${ }^{157}$ In the same year, the ECHR issued a whopping 958 final judgments and disposed of an additional 27,600 applications. ${ }^{158}$ Although Posner and Yoo find it difficult to corroborate the assertion, ${ }^{159}$ they note that the ECHR has a reputation for

149. European Convention for the Protection of Human Rights and Fundamental Freedoms art. 19, Nov. 4, 1950, 213 U.N.T.S. 221 [hereinafter European Convention].

150. Id. art. $46(1)$.

151. European Court of Human Rights, Information Document on the Court, http://www.echr.coe.int/NR/rdonlyres/981B9082-45A4-44C6-829A-202A51B94A85/0/

InformationdocumentontheCourt_September2006_.pdf (last visited Aug. 5, 2008).

152. Id.

153. European Court of Human Rights, The Budget of the Court, http://www.echr.coe.int/ECHR/EN/Header/The+Court/The+Budget/Budget/ (last visited Aug. 5, 2008).

154. Converted on October 24, 2006.

155. European Convention, supra note 149, arts. 34, 35(1).

156. Id. art. 34.

157. European Court of Human Rights, Information Document on the Court, http://www.echr.coe.int/NR/rdonlyres/981B9082-45A4-44C6-829A-202A51B94A85/0/

InformationdocumentontheCourt_September2006_pdf (last visited Aug. 5, 2008).

158. Id.

159. Posner and Yoo, supra note 82, at 65-66. 
enjoying a high level of compliance. ${ }^{160}$

Clearly, the ECHR is a different breed of international tribunal. Here we see true delegation, the type that contemplates and receives the surrender of certain aspects of state sovereignty. Indeed, when other alleged instances of delegation are compared to this exceptional case, the differences are large and striking. The fact that this kind of delegation only occurs here, in the context of a highly integrated set of states, may suggest some conditions required for real delegation-conditions that exist almost nowhere else.

\section{CONCLUSION}

The international community faces a range of important and challenging problems. Some of the most serious-war, poverty, environmental degradation, nuclear proliferation, and disease--pose threats that are global in magnitude. Solutions to these problems will require collaboration among states and likely various forms of delegation to international organizations. This is reason enough to study delegation and to learn why and when states are willing to give up authority to some other body.

This Essay has the modest goal of reminding us that the puzzling thing about the delegation we observe in the world today is that there is so little of it. States have consistently refrained from handing over significant authority to international bodies. Almost without exception, an examination of specific examples of delegation reveals that states have retained considerable control. To begin with, the most powerful form of authority-the authority to legislate-is almost never delegated by states. Where some form of decisionmaking authority is granted, it is typically an exceedingly narrow authority over highly technical matters. Instead, the most significant forms of delegation in place today tend to be adjudicatory.

Given the few-and limited-examples of international delegation that we can identify, there is a real mystery about why states have been so protective of their sovereignty in the face of severe international problems that cry out for collective decisions and often for decision-making rules that do not demand unanimity before action is taken. With respect to debates about delegation in both academic and policy circles, the lesson from this Essay is that when claims are made about international delegation and how it is or will be a threat to sovereignty, one should ask for examples. Concerns about international delegation are understandable. The specter of international bureaucrats imposing policy on us all while fundamental aspects of sovereignty are trampled is frightening. Fortunately it is, in the end, a myth.

160. Project on International Courts and Tribunals, http://www.pictpcti.org/courts/ECHR.html (last visited Aug. 5, 2008) ("Unlike in the cases of many other fora, compliance with the ECHR's judgments is common, exerting a deep influence on the laws and social realities of member States."). 
